\title{
Effect of the War on American Industries-I
}

\author{
Permanent Value to Manufacture on Our Soil with Our Native Raw Materials
}

\author{
By Edward Ewing Pratt, Chief, Bureau of Foreign and Domestic Commerce
}

A PSYCHOLOGICAL study of the average American A citizen, during these past months of intense absorption in the world conflict across the waters, would reveal a marvelous composite of mental moods-wholehearted sympathy with the millions of sufferers, fears for the test to which democratic ideals are being subjected, longing for permanent relief from the possibility of war in the future, and the heavy burden of military preparation, anxiety for the maintenance of our own position, as the one powerful nation not involved in the terrific clash of arms, and a score of other feelings connected with sentiment, duty or interest.

Prominent among these are the instinctive questions arising as to the effect of the world's turmoil on our own people. What will be the outcome in regard to our political institutions, our standards of international morality, our future relations to the different contestants in the bitter struggle, our whole fabric of American life, social, intellectual, spiritual, and material? A small army of experts in all the fields of human activity are tasked to consider all of the queries in this connection. My own daily duties require me to study closely one of the many fields involved, that of the nation's industries, as affected by the Great War, and as a close corollary, the effect upon the exchange of the products of these industries, i. e., our. own nationa commerce, domestic and foreign.

The influence of the war upon our American industrial life is of a two-fold nature. There are direct, visible results, essentially of a transitory nature, and destined to terminate with the approach of peace. There are other results, less evident to the eye, but increasing. with each added day of the conflict, and bound to be of far-reaching import in the evolution of our industries.

In the first category falls the feverish activity developed in connection with the effort to swiftly supply the enormous needs of four nations in arms. We are furnishing not simply vast quantities of livestock and foodstuffs, but almost as great amounts of everything needed to equip armies, and repair the heavy wastage of war-shoes, wearing apparel, saddlery, motor trucks, all possible forms of railway material, iron and steel in multitudinous shapes, such as barbed wire, bridge material, etc., lead, zinc and copper, especially the last two, fire-arms of every description, from revolvers to siege guns, cartridges and particularly shells. These are leading items. A detailed list would resemble the inventory of a country store.

All of this commercial movement will cease with the order to "break ranks" in Eastern and Western Europe. It will exert no enduring influence on the development of our industrial life, as far as new markets for its products come into consideration. The only after effects demanding attention are those connected with our domestic economic condition when these vast war contracts expire.

For the time being, the exceptional activity of the branches enumerated has been of material aid in the general recovery throughout our land from an industria depression, shared in common with the rest of the world, and due to the economic reaction following the recent Balkan wars. In each of the branches in ques tion, every workman already skilled in any one of the varied processes is steadily occupied, and thousand of men and women, unemployed for months before have been swiftly trained to novel manipulations. The result has been a most welcome solution of the problem of unemplosment in scores of manufacturing centers. An equally unwelcome experience will probably follow any sudden cessation in the call for supplies and munitions; when the warring millions of Europe return to their deserted work-benches; looms and furnaces, and the abnormal activity of American mills and factories comes to an abrupt close

In what condition will these varied plants be left, a the approaeh of peace? In some categories there have been no material addition to buildings and equipment. This is essentially the case with our flouring mills, tanneries, harness shops, shoe factories, and clothing fac tories. Their capacity has been taxed to the utmost, but no notable additions to plants are recorded.. Some but no notable additions to plants are recorded.. Som enlargement in the case of shoe machinery ant
slightly the normal necessities of replacement.

In the case of machine tools, there has been great difficulty in meeting the urgent demands for lathes to turn the millions of steel shells for which contracts have been taken in this country. The rigid requirements in regard to the diameter of shells. involve the use of lathes of the highest precision and accuracy. The advent of peace will find thonsands of lathes doomed to idleness throughout the eastern tier of Northern States. This excess will possibly be gradually worked off in supplying foreign markets at reduced rates. In practically all cases, the cost of this extra mechanical equipment has been written off in the high prices charged for munitions. It is to be noted, however, in this connection, that the foreign demand for metal-working machinery, especially lathes, has augmented in unprecedented proportions. Thus, in the month of May, 1915, the values of our exports under this category, as com pared with those of May, 1914, were as follows

\begin{tabular}{|c|c|c|}
\hline To- & 1914 & 1915 \\
\hline $\begin{array}{l}\text { Canada } \\
\text { France }\end{array}$ & $\$ 69,000$ & $\$ 292,000$ \\
\hline United Kingdom..... & 281,000 & $\begin{array}{l}1,225,000 \\
1,737,000\end{array}$ \\
\hline Australia ....... & $\ldots \ldots$ & 22,000 \\
\hline
\end{tabular}

It is evident that we are not only meeting an urgen present need in the above countries, but that we are shipping such a stock that the normal needs of the lands in question will be covered for years to come. In addition, the high qualities of American machine tools have received a magnificent advertisement, and business relations have been established, which may be ulti

The manufacture of rifles, cartridges, fuses for shells etc., has called for a great multiplication of specialized mechanical equipment, much of which cannot be very advantageously utilized in times of peace. Some ma be sold to foreign arsenals. The rest forms an im portant asset in the nation's material resources for de fense against invasion.

The normal equipment of our steel works has thus far been adequate to furnish the necessary supplies required in the manufacture of shells. Far otherwise is the case with regard to the contents of these shells. Our factories for the production of high explosives were totally unprepared to furnish more than a fraction of the tons and tons of picric acid and trinitro-toluol needed on the firing lines in Europe. It meant the construction of extensive new plants for the manufacture of the deadly compounds. It meant further an enormous expansion in the output of nitric acid and sulphuric acid, required to change phenol and toluol into explosive forms. The tar works of the country could supply but a very limited amount of phenol or carbolic acid. It wa necessary to manufacture it on a large scale, synthetically from pure benzol, involving an additional large consumption of sulphuric acid and of caustic alkalies and an extensive mechanical plant. The current supply of benzol and toluol-important hydrocarbons. found among the multitude of products formed in the distillation of coal-was, however; far from meeting this new demand. At once recovery devices were installed in connection with many of our great coke plants, and the two valuable products were carefully separated and collected, instead of being wasted in the air, or used as fuel.

At the close of the war all of the newly organized works now devoted to making explosives will be idle Their initial cost has, however, been amply covered by the high prices paid for the products, and they remain in perfect condition to resume operations in case ou Government must engage in warfare-another national asset in the line of "preparedness."

Increased plant for the manufacture of the two acids mentioned above would inevitably be necessary at an early date, under normal circumstances, to meet the wants of our steadily expanding chemical industry, especially for use in making fertilizers. The forcible utilization of the by-products of our coke works is, however, an economic gain of prime importance. The end of the war will find us in a position to supply all of the crude material needed in the manufacture of such artificia dye-stuffs as the country has hitherto imported from Europe, and in the preparation of a variety of medicinal and allied compounds, for which we have also depended upon foreign sources.

The manufacture of automobiles, especially of moto trucks, to fill foreign orders has received a powerful impulse. In May, 1914, the value of such exports was $\$ 2,985,000$. In May, 1915 , it reached $\$ 10,555,000$. We
shipped 663 automobiles to Great Britain in May, 1914 The number grew: to 4,036 in May, 1915

This has necessarily required notable additions to plants; but not more, probably, than the natural growth of the industry would have demanded in the course of the next two or three years. The value and efficiency of the American auto, under conditions of the most exacting nature, have, however, been abundantly demon- strated throughout Europe, and this advertising on a vast scale, by way of first-hand demonstration, will certainly prove to be an exceptional aid in enlarging the European market for American cars.

A review of the chief industries, ministering particularly to the temporary needs of the belligerents across the Atlantic, shows clearly that the final outcome will be a very material addition to the manufacturing plant of the United States. Part of this plant will be simply anticipatory of the normal growth of the country's mechanical equipment; part must lie idle in time of peace, but is a distinct asset in the national preparation for an adequate defense against attack; the remainder furnishes at once products needed in the healthful expansion of our chemical industry.

Less conspicuous and spectacular, but of far greater permanent value, is the impulse given to the manufacture on American soil, with American raw materials, of a variety of articles, for which we have hitherto been dependent upon foreign skill and enterprise. In a more or less uncomfortable way, we have suddenly been brought to recognize the unwisdom, the folly, of shipping vast amounts of the crude material of our farms, forests and mines, three thousand miles across the ocean and buying it back in a manufactured form at a vastly enhanced price. We have likewise come to recognize the absurdity of allowing many natural product of the tropics, of South America, of the Far. East, to find their way to Europe, and of paying foreign intelligence and skill to transform them into articles of daily need in our lives.

The complete cessation of imports from Germany and Austria, and the serious restriction in our purchases from many other countries, have taught us these two sons that the American people will derive its chief benefit from this otherwise so deplorable world conflict American skill, ingenuity, adaptation, inventive talent, scientific attainments, and general enterprise have promptly raflied to meet widespread demands, and establish on our own soil the permanent manufacture of a number of wares, some of minor, others of major importance. The return of peace will see them well rooted and able to withstand foreign competition.

I might briefly cite a few illustrative instances.

The curved faces of our clocks and watches have fon many years come to us exclusively from Germany. Last autumn, the imports ceased. Manufacturers of time-pieces laid their needs before leading American glassmakers. Within a month the problem was solved. The curved disks were made a regular article of manufacture, and the quality was beyond criticism. A second month passed, and the cost of production was reduced to a figure below the former current prices of German manufacturers.

Another case. There is a large consumption in this country of small, fine brushes, for water colors. The supply was entirely of German origin. It suddenly ceased. Promptly an American firm started the manufacture. It was found that the essential raw material consisted of fine hairs from the inside of the ears of cattle. German makers secured their supplies from the slaughter houses of Chicago. The steers of the Western plains will henceforth contribute their quota to American artistic activity without any necessity that it should make a double trip across the Atlantic.

Barium minerals are unusually abundant in the United States. Yet, we have imported in the past over 17,000,000 pounds annually of the various barium salts required in the arts. During the past twelve months one establishment has introduced the manufacture on a large scale of the chloride, carbonate, etc. from domestic raw material, and another will soon begin operations. Both utilize the vast deposits of barytes in Tennessee, Georgia, and North Carolina. ( $T$ o be comtinued.)

Two Controls for Automobiles.-Clark T. Henderson of Milwaukee, assignor to the Cutler Hammer Mfg. Company, has secured patent No. 1,143,195 for an automobile in which two driving seats and duplex control for each of the seats is provided, so that the operator may sit on the front or rear seat as desired and operate the machine from either seat. The front seat is movable so that it can be shifted out of the way when the driver is operating from the rear seat. This movable front seat, when in driving position, covers the foot lever of the control of the rear seat. Hence, the foot lever is not accessible to those on the rear seat, thereby avoiding not accessible to those on the rear seat, thereby avoiding
interference with the control by the use of the rear lever when the chaufeur is operating from the front. 